\title{
Variation in selenium tolerance among two onion cultivars in closed fortification system
}

\author{
Domokos-Szabolcsy, É., Barnóczki, A., Prokisch, J., Sztrik, A. \& Fári, M.G. \\ University of Debrecen Centre of Agricultural Sciences, Instute of Diószegi Sámuel Agrarinnovation, \\ 4032 Debrecen,Egyetem tér 1., Hungary, szabolcsy@agr.unideb.hu
}

\begin{abstract}
Summary: Selenium (Se) is an essential trace element for humans and animals. To consumption of selenium could be good sources the vegetables. Many of them are able to convert the inorganic selenium forms to organic forms, which are more effective for health. To enrich onion with selenium is known however some unclear points are remained.

A closed fortification system was conducted to compare the difference of selenium tolerance in two onion cultivars in greenhouse environment. This system was well controlled, eliminating a lot of disturbing factors. The comparative analysis of Makói bronz and Makói lila spring onoins showed that there is difference in selenium tolerance and accumulation not only between plant species but inside it between the different cultivars, too. The Makói bronz seemed to more sensitive to the selenate treatment than Makói lila.
\end{abstract}

Keywords: spring onion, cultivars, biofortification, closed system, selenium tolerance

\section{Introduction}

Selenium is an important trace element from environment and biological point of view being essential in a very narrow concentration range while outside of this range deficiency or toxicity occurs (Sager, 2006). Worldwide deficiency of selenium in diet is more common than its abundance and nutritional supplements have been recommended to increase daily Se intake.

There is growing market on the development of high-Secontaining supplements, including yeast-based formulations, appears to be an effective and a safe option for human subjects (McSheehy et al., 2006; Mapelli et al., 2011; Rayman, 2004). Besides this the most frequent ways to increase the amount of selenium in human is to use Se as soil or leaf fertilizers or treat the seeds with an aqueous selenium (Ahmed, 2010; Carvalho et al., 2003; Germ et al., 2007). The biggest problem with Se fertilization practice is the uncontrolled over-uptake, which might result in possible environmental problems (Makela et al., 1995). However selenium enriched vegetables and crops could be good possibility to reduce dietary deficiencies and increase health benefits (Broadly et al., 2006). Thus it is important to find plants capable to tolerating and transforming selenium into bioactive compounds. Allium and Brassica species seem to be good sources. Several studies proved that in this selenised vegetables the main selenium forms are Se-methylselenocysteine and derivates which are known as very effective forms for health protection (Ip et al., 2000; Hama et al., 2008; Abdulah et al., 2009).

In our experiments we tried to create a closed fortification system to growth selenium enriched spring onions during we protect the environment from the applied selenium supplement. In this system we compared the selenium tolerance and accumulation capacity of two cultivars of Allium cepa.

\section{Materials and methods}

\section{Fortification of green onion used by sodium-selenate}

Two different cultivars Allium cepa cv. 'Makói bronz', and 'Makói lila' and treatment with selenium in the form of sodium-selenate were used. The commercial-size onion bulbs were planted into perlite bed in propagating trays. The applied selenate concentrations were $0,2,5,10 \mathrm{mg} / \mathrm{l}$ one time after just distilled water was used for irrigation.

Cultures were maintained under natural photoperiod. To decrease the light intensity Raschel-net was taken on the windows. After three weeks the newly developed spring onions were separated from the mother onions.

\section{Measurements from green onions}

The fresh weight of spring onions was measured. The length of them was also measured by COLIM color image classification program Dry matter content was determined after freeze drying by a lyophilizer (Alpha 1-4 LSC Christ, Germany).

Total selenium concentration was determined by AFS atomfluorescent spectroscopy technics (AFS, Millennium System, P.S. Analytical Ltd., England). Selenium hydride was generated in a flow injection system. A flow rate of 1.5

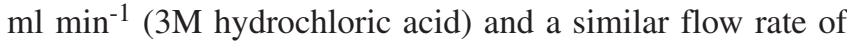
the reductant solution $(1,4 \mathrm{~m} / \mathrm{V} \%$ sodium tetrahydroborate) 
were used to generate the selenium hydride. The AFS method was used, based on that described by Dernovics et al., (2002); Cabanero et al. (2004), modified for the tobacco being studied.

For the sample preparation $0.2 \mathrm{~g}$ lyophilized sample was digested with $2 \mathrm{ml}$ nitric acid in an analytical fracturer at 100 ${ }^{\circ} \mathrm{C}$ for $1 / 2 \mathrm{~h}$ and then $1 \mathrm{ml}$ hydrogen peroxide was added at $120{ }^{\circ} \mathrm{C}$ for $45 \mathrm{~min}$ in closed system was followed by reduction of $\mathrm{Se}^{\mathrm{VI}}$ to $\mathrm{Se}^{\mathrm{IV}}$. Detection of $\mathrm{Se}^{\mathrm{IV}}$ was done. The solutions were then diluted to $10 \mathrm{ml}$ with Milli-Q water (Millipore, Malsheim, France).

Data were analyzed using one-way analysis of variance (ANOVA) at 95\% confidence interval in SPSS 14.0 version. Significantly different means between treatments were separated using the Games-Howell test.

\section{Results and discussion}

The onions such as Allium tricoccum, Allium sativum are able to accumulate the selenium in higher amount without any toxic symptoms in biomass production (Montes-Bayon et al., 2006; Whanger, 2000). So the different type of onions could be suitable to produce selenium-enriched functional vegetables.

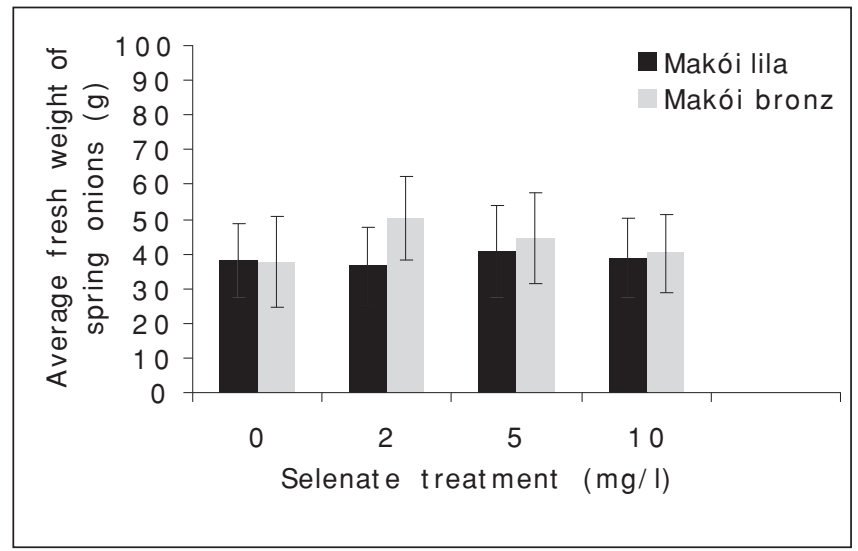

Fig.1: Average fresh weight of Makói bronz and Makói lila spring onions depending on selenate treatments $(\mathrm{p}<0,05)(+/-\mathrm{SE})$

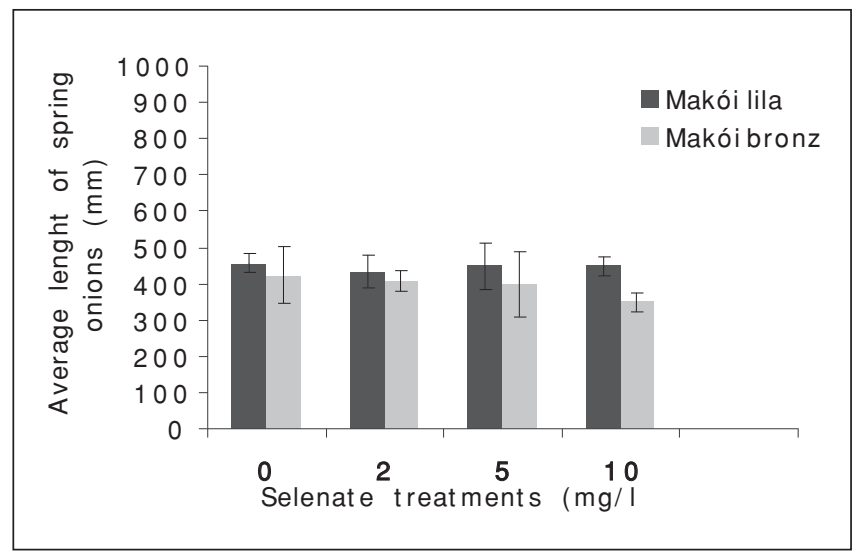

Fig. 2: Average length of Makói bronz and Makói lila spring onions depending on selenate treatment $(\mathrm{p}<0,05)(+/-\mathrm{SE})$
In our experiment no visual changes in health were observed in selenium treated plants in comparison with untreated ones. The treatment with sodium-selenate $(0-10$ $\mathrm{mg} / \mathrm{l})$ concentrations did not influence significantly the development of Makói lila spring onion to see the weight and length (Fig.1, 2). In case of Makói bronz the applied selenium concentration didn't influenced the fresh weight significantly, but $10 \mathrm{mg} / \mathrm{l}$ has already caused a significant decrease in length. The obtained results were confirmed by visual experience as well: the treated spring onions were shorter, but thicker compared to the control. (Fig. 1, 2).

To see the dry matter content we found that the sodiumselenate did not effect significantly it in the applied selenium concentrations in neither of cultivars. The difference in dry matter content between cultivars was prevailed more (Fig. 3). The dry material values of Makói bronz were much higher $(0,145-0,175 \mathrm{~g} / \mathrm{g})$, than in case of Makói lila $(0,087-0,101$ $\mathrm{g} / \mathrm{g}$ ). The variability of average dry matter content in onion bulbs was influenced by genetic variance higher than the ecological impacts found by Pavlovic et al. (2007), too.

The total selenium content of spring onions increased proportionately with the applied selenate concentration. To compare the two onion cultivars it was no remarkable difference between their selenium accumulating abilities (Fig. 4).

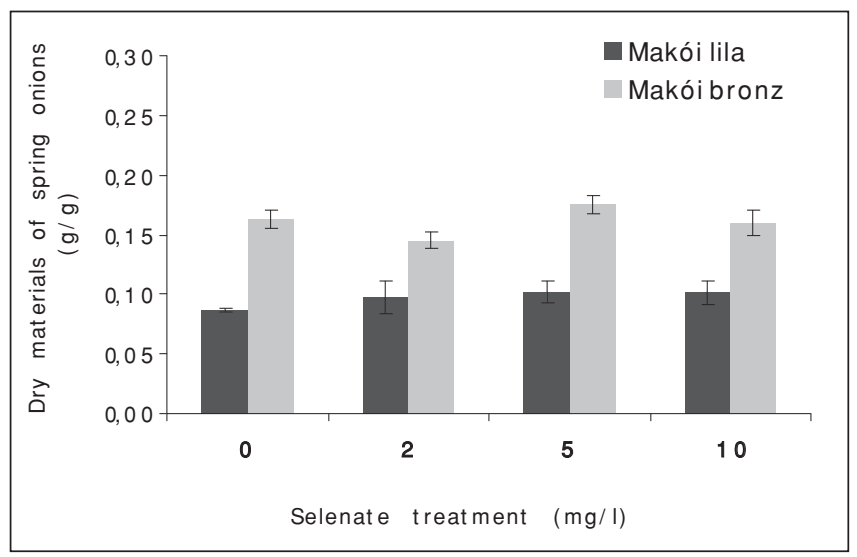

Fig. 3: Dry matter content of Makói bronz and Makói lila spring onions depending on selenate treatments $(\mathrm{p}<0,05)(+/-\mathrm{SE})$

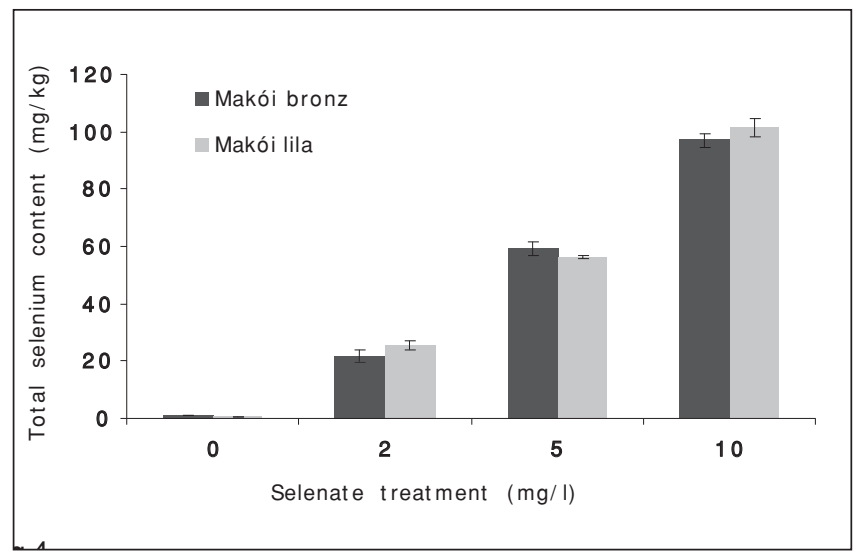

Fig 4: Total selenium content of Makói bronz and Makói lila spring onions depending on selenate treatments $(\mathrm{p}<0,05)(+/-\mathrm{SE})$ 


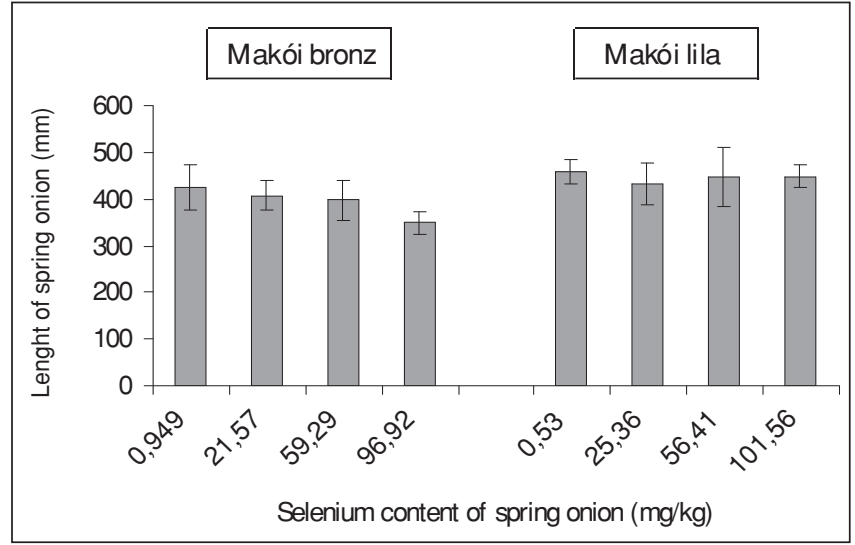

Fig. 5: Correlation between length and total selenium content of spring onion

The Makói bronz cultivar seemed to be more sensitive for the increasing selenate treatment than Makói lila. The accumulated selenium $(96,92 \mathrm{mg} / \mathrm{kg}$ ) caused significant decrease in the length of Makói bronz, but 101,56 mg/kg Se content didn't evoke any negative effect for the length of Makói lila (Fig. 5). Substantial variation was also found between the Arabidopsis thaliana cultivars with respect to both Se tolerance and accumulation as was shown by Zhang et al. (2007). In general ecotypic variation with regard to tolerance and accumulation of metals is a common phenomenom (Baker, 1987; Macnair et al., 1999)

Onion bulbs planting into perlite bed in a closed system could be good controlled and environmentally friendly process to obtain fortificated spring onion. To use this way we compared the selenium tolerance and accumulation of two onion cultivars. The results showed that the Makói bronz is more sensitive to the selenium treatment than Makói lila. However the selenate in $\leq 10 \mathrm{mg} / \mathrm{l}$ concentration range could be applied to produce selenium enriched spring onion.

\section{References}

Sager, M. (2006): Selenium in agriculture, food and nutrition. Pure Appl. Chem., 78: 111-133

McSheehy, S., Yang, L. \& Mester, Z. (2006): Selenomethionine extraction from selenized yeast: an LC-MS study of the acid hydrolysis of a synthetic selenopeptide Microchim. Acta, 155: 373-377.

Mapelli, V., Hillestrom, P.R., Kápolna, E., Larsen, E.H. \& Olsson, L. (2011): Metabolic and bioprocesses engineering for production of selenized yeast with increased content of selenomethylselenocysteine Metab. Eng., 13: 282-293.

Germ, M., Stibilj, V., Osvald, J. \& Kreft, I. (2007): Effect of selenium foliar application on chicory (Cichorium intybus L.) J. Agrci. Food Chem., 55: 795-798.

Carvalho, K.M., Gallardo-Williams, M.T., Benson, R. \& Martin, D.F. (2003): Effects of selenium supplementation on four agricultural crops J. Agric. Food Chem., 51: 704-709.
Ahmed H.Kh. (2010): Differences between some plants in selenium accumulation from supplementation soils with selenium Agric. Biol. J. North Am., 1(5): 1050-1056

Makela, A.L., Wang, W.C., Hamalainen, M., Nanto, V., Laihonen, P., Kotilainen, H., Meng, L.X. \& Makela, P. (1995): Enviromental effects of nationwide selenium fertilization in Finland. Biol. Trace Elem. Res., 47: 289-298

Rayman, M.P. (2004): The use of high-selenium yeast to raise selenium status: how does it measure up? Brit. J. Nutr., 92: 557-573

Broadly, M.R., White, P., Bryson, R.J., Meacham, M.C., Bowen, H.C., Johnson, S.E., Hawkesford, M.J., McGrath, S.P., Zhao, F-J, Breward, N., Harriman, M. \& Tucker, M. (2006): Biofortification of UN food crops with selenium Proceed. Nutr. Soc., 65: 169-181

Ip, C., Birringer, M., Block, E., Kotrebai, M., Tyson, J.F., Uden, P.C., Lisk \& D.J.: (2000): Chemical Speciation Influences Comparative Activity of Selenium-Enriched Garlic and Yeast in Mammary Cancer Prevention J. Agric. Food Chem., 48: 2062-2070.

Hama, H., Yamanoshita, O., Chiba, M., Takeda, I. \& Nakajima, T.: (2008): Selenium-enriched Japanese radish sprouts influence glutathione-peroxidase and glutathione S-transferase in an organspecific manner in rats J. Occup. Health, 50: 147-154.

Abdulah, R., Farjed, A., Kobayashi, K., Yamazaki, C., Suradi, E.W., Ito, K., Suzuki, K., Murakami., Kuwano, H. \& Koyama, H.: (2009): Selenium enrichment of broccoli sprout extract increases chemosensitivity and apoptosis of $\mathrm{LNCaP}$ prostate cancer cells, BMC Cancer, 9: 414-426.

Cabanero, A.I., Madrid, Y. \& Camara, C.: (2004): Selenium and mercury bioaccessibility in fish samples: an in vitro digestion method, Analytica Chimica Acta, 526: 51-61.

Dernovics, M., Stefánka, Zs. \& Fodor, P. (2002). Improving selenium extraction by sequential enzymatic processes for Sespeciation of selenium-enriched Agaricus bisporus. Analytical and Bioanalytical Chemistry, 372: 473-480.

Montes-Bayón, M., Diaz Molet, M.J., Blanco Gonzalez, E. \& Sanz-Mendel, A.: (2006): Evaluation of different sample extraction strategies for selenium determination in selenium-enriched plants (Allium sativum and Brassica juncea) and Se speciation by HPLCICP-MS Talanta, 68: 1287-1293

Whanger, P.D., Ip, C., Polan, C.E., Uden, P.C. \& Welbaum, G.: (2000): Tumorgenesis, metabolism, speciation, bioavailability and tissue deposition of selenium in selenium-enriched ramps (Allium tricoccum). Journal of Agricultural and Food Chemistry, 48: 5723-5730.

Zhang, L., Ackley, A.R. \& Pilon-Smits, E.A.H. (2007): Variation in selenium tolerance and accumulation among 19 Arabidopsis thaliana accessions, J. Plant Phys., 164: 327-336

Baker, A.J.M. (1987): Metal tolerance, New Phytol., 106: 93-11.

Macnair, M.R., Bert, V., Huiston, S.B., Saumitou-Laprade, P. \& Petit, D. (1999): Zinc tolerance and hyperaccumulation are genetically independent characters. Prot. R. Soc., B266: 2175-2179

Pavlovic, N., Cvikic, D., Zdravkovic, M., Dordevic, R. \& Prodanovic, S. (2007): Variability and heritability coefficient of average dry matter content in onion (Allium cepa L.) bulbs. Genetika, 39: 63-68. 